\title{
Adsorption of copper and zinc onto natural clay in single and binary systems
}

\author{
A. T. Sdiri $\cdot$ T. Higashi $\cdot$ F. Jamoussi
}

Received: 14 August 2012/Revised: 27 September 2012/Accepted: 23 April 2013/Published online: 17 May 2013

(C) Islamic Azad University (IAU) 2013

\begin{abstract}
Calcareous and smectitic clay samples from the Coniacian-Lower Campanian system, Tunisia, were used as adsorbents for the removal of copper and zinc from aqueous solutions in single and binary systems. Calcareous clay sample was treated with acetic acid to obtain carbonate-free sample that was also used for metals removal. The adsorption of metal ions onto natural clay was tested in a batch method by mixing $1 \mathrm{~g} / \mathrm{L}$ of each sample with a metal ion solution of zinc $(300 \mu \mathrm{mol} / \mathrm{L})$ and/or copper $600 \mu \mathrm{mol} / \mathrm{L}$ under the operating $\mathrm{pH}$ of 6 , and agitation speed of $200 \mathrm{rpm}$ within the equilibrium time of $60 \mathrm{~min}$ at $25{ }^{\circ} \mathrm{C}$ for single and binary systems. Our results showed that natural clay samples were mainly composed of silica, alumina, iron, and magnesium oxides. Adsorption data showed that the studied clay samples removed substantial amounts of heavy metals in single and mixed systems. Initial solution $\mathrm{pH}$ and carbonates contents enhanced the removal capacities of the studied clay samples, confirming their strong influencing effects. Thermodynamic parameters indicated an endothermic adsorption for metals removal by calcareous clay, but exothermic process for the smectitic sample. These results suggest that the Late
\end{abstract}

A. T. Sdiri $(\bowtie) \cdot$ T. Higashi

Faculty of Life and Environmental Sciences, University of Tsukuba, 1-1-1 Tennodai, Tsukuba 305-8572, Japan e-mail: alisdiri@yahoo.fr

\section{A. T. Sdiri}

National Institute for Materials Science, 1-2-1 Sengen, Tsukuba 305-0047, Japan

A. T. Sdiri · F. Jamoussi National Center for Materials Science, 273-8020 Borj Cédria, Soliman, Tunisia
Cretaceous clays, Tunisia, can be effectively used as natural adsorbents for the removal of toxic heavy metals in aqueous systems.

Keywords Clays · Competitive Langmuir model · Heavy metals $\cdot$ Thermodynamic $\cdot$ Sorption

\section{Introduction}

Various industrial processes, including metal plating, fertilizer production, mining, metallurgy, battery manufacturing and textile dyeing, and others, are the main sources of heavy metals (Barhoumi et al. 2009; Messaoudi et al. 2009; Eloussaief and Benzina 2010). The fate of the metals in aquatic system can be variable, depending upon their initial form and the chemical and physical characteristics of the receiving water body. Metals may be in solution as free ions, soluble salts, associated ions with dissolved inorganic or organic ligands, or bound to particulate matter. Unlike organic contaminants, heavy metals are non-biodegradable; they accumulate in living organisms causing adverse effects to many vital functions. That is why toxic metals like zinc, copper, nickel, mercury, cadmium, lead, and chromium have to be removed from industrial wastewaters before being discharged in the ecosystem. Remediation of metal-contaminated media is a time-consuming and expensive process. The use of natural clays in the removal of $\mathrm{Cu}$ (II) and $\mathrm{Zn}$ (II) from aqueous solutions is of particular interest for environmental cleanup since the use of natural adsorbents is particularly beneficial for the development of cost-effective process for heavy metal removal from wastewaters. Adsorption is the most preferred method for removal of heavy metals from aqueous solutions due to its simplicity and its high 
effectiveness (Sdiri et al. 2011, 2012a, b). In this regards, multiple researchers studied the effectiveness of various type of clay in removing heavy metals from aqueous solutions including kaolinite (Sari et al. 2007; Schaller et al. 2009), bentonite (Ulmanu et al. 2003; Kaya and Hakan Ören 2005; Eren et al. 2009), illite (Ozdes et al. 2011), sepiolite (Guerra et al. 2010), montmorillonite (Lin and Juang 2002), and other adsorbents (Al-Degs et al. 2006; Engates and Shipley 2011). Many other studies have been undertaken to evaluate the adsorptive capacity of various bioadsorbents in the removal of inorganic pollutants (Ahmad et al. 2010; Das 2012; Dubey and Shiwani 2012; Revathi et al. 2012; Eren 2010). They found that those cheap adsorbents could be used in the removal of different metal cations [e.g., $\mathrm{Cd}(\mathrm{II}), \mathrm{Pb}(\mathrm{II})$, $\mathrm{Cu}(\mathrm{II}), \mathrm{Zn}$ (II) ... etc.]. For instance, Ahmad et al. (2010) used activated sludge biomass (ASB) for the biosorption of $\mathrm{Cd}(\mathrm{II}), \mathrm{Pb}(\mathrm{II})$, and $\mathrm{Zn}$ (II). They mentioned that ASB removed substantial amounts of $\mathrm{Cd}$ (II) and $\mathrm{Pb}$ (II), but low quantity of $\mathrm{Zn}(\mathrm{II})$. Wang and $\mathrm{Li}$ (2009) investigated the competitive removal of copper and nickel by non-living biomass, showing that $\mathrm{Cu}(\mathrm{II})$ was preferably adsorbed over $\mathrm{Ni}(\mathrm{II})$. Those studies were limited to the adsorption of single metals, despite the fact that contaminated wastewaters contain more than one pollutants [e.g., $\mathrm{Pb}(\mathrm{II})$, $\mathrm{Cd}(\mathrm{II}), \mathrm{Cu}(\mathrm{II})$, and $\mathrm{Zn}(\mathrm{II})]$ that have to be removed before the final discharge in the receiving ecosystems. The Coniacian-Lower Campanian clays of the Aleg formation, Tunisia, showed high adsorptive capacities for heavy metal (Sdiri et al. 2011, 2012b). While most sorption studies that are conducted on clays usually start by the removal of non-clay minerals (e.g., carbonate minerals, and quartz) in order to concentrate the clay minerals and improve the sorption properties of the adsorbent (Al-Degs et al. 2006), the effects of carbonates impurities have not been studied in details. Adsorption onto cost-effective natural materials is the most commonly utilized technique due to its simplicity when compared to other methods like ion exchange and precipitation. Therefore, we attempted to study the effects of carbonate minerals as well as the competitive cations on the adsorption of heavy metals by calcareous and smectitic clays. Moreover, natural clay samples without any pre-treatment were used in order to decrease the cost of the removal process. The importance of understanding the mechanisms involved in heavy metals removal from wastewaters is a cornerstone in the elucidation of the interactive mechanism between both clay and metal removed, and between metal cations [i.e., $\mathrm{Cu}(\mathrm{II})$ and $\mathrm{Zn}(\mathrm{II})]$ in binary system.

This work has been carried out in the laboratory of Soil Environmental Chemistry, Faculty of Life and Environmental Sciences, University of Tsukuba, and finalized at the National Institute for Materials Science, Japan. Most of the adsorption experiments were performed in 2012.

\section{Materials and methods}

\section{Characterization of clay}

The calcareous clay sample was collected from the Coniacian-Early Campanian outcroppings of the Gafsa area (south of Tunisia). To study the effect of carbonate minerals on the adsorptive capacity, the collected sample was treated with acetic acid $(1 \mathrm{~mol} / \mathrm{L})$ in a water bath at $80{ }^{\circ} \mathrm{C}$. Both original and carbonate-free clay materials were saturated with $1 \mathrm{M} \mathrm{NaCl}$ solution. The obtained $\mathrm{Na}^{+}$homoionic clay samples were then dialyzed several times to remove chloride (Jarraya et al. 2010). Finally, $\mathrm{Na}^{+}$homoionic clay materials were dried at $105{ }^{\circ} \mathrm{C}$ for $24 \mathrm{~h}$ and then crushed to collect the desired particle size ranges of $<210 \mu \mathrm{m}$. Hereafter, we use the abbreviations RS and TS to refer to original and treated clays, respectively. To clarify the effects of carbonates on the adsorption process, additional smectitic clay (RY), collected from the Gabes area, was used for comparative purposes (Sdiri et al. 2011, 2012b).

Chemical compositions of the original and treated samples were determined by subjecting the pelleted clay powders to an electron microprobe equipped with X-ray dispersive spectrometer (JXA8621 Superprobe; JEOL, Japan). $\mathrm{N}_{2}$ adsorption methodology was used for porosity measurement using Coulter instrument (SA3100, Beckman Coulter, USA). The adsorbent was also characterized using an FT-IR spectrophotometer (FT-720; Horiba Ltd., Japan) at room temperature.

\section{Batch adsorption}

All the chemicals used were of analytical reagent grade supplied by Wako Pure Chemical Industries, Ltd. (Japan). Stocks of copper and zinc solutions $(1,000 \mathrm{mg} / \mathrm{L})$ were prepared by dissolving appropriate amounts of $\mathrm{CuCl}_{2} \cdot 2 \mathrm{H}_{2} \mathrm{O}$ and $\mathrm{ZnCl}_{2}$ in $1,000 \mathrm{~mL}$ of ultrapure water. Working standards were prepared by dilution of the stock solution. $0.1 \mathrm{M} \mathrm{HCl}$ and $0.1 \mathrm{M} \mathrm{NaOH}$ solutions were used for $\mathrm{pH}$ adjustment. The adsorption of metal ions [i.e., $\mathrm{Cu}$ (II) and $\mathrm{Zn}$ (II)] onto natural clay was tested in a batch method by mixing $1 \mathrm{~g} / \mathrm{L}$ of each original (RS and RY) and treated (TS) sample with a metal ion solution of $\mathrm{Zn}$ (II) $300 \mu \mathrm{M}$ and $\mathrm{Cu}$ (II) $600 \mu \mathrm{M}$ under the operating $\mathrm{pH}$ of 6 , and agitation speed of $200 \mathrm{rpm}$ within the equilibrium time of $60 \mathrm{~min}$ at $25{ }^{\circ} \mathrm{C}$ for single and binary systems, unless otherwise specified by the study design (i.e., to examine the 
effects of $\mathrm{pH}$, temperature, initial metal concentration, and contact time). After shaking, $10 \mathrm{~mL}$ of supernatant were withdrawn and filtered with $0.45 \mu \mathrm{m}$ syringe driven filter (Millex-LH, PTFE, Millipore Corp., Ireland). The filtrates were analyzed for the $\mathrm{Cu}$ (II) and $\mathrm{Zn}$ (II) concentrations using an ICP-AES Instruments, Optima 7300 DV series (PerkinElmer Inc., Japan). All experiments were run in triplicate.

The amount of removed heavy metal $(\mu \mathrm{mol} / \mathrm{g})$ was calculated from the difference between initial and final concentrations as defined by the following equation:

$q_{e}=\frac{\left(C_{0}-C_{e}\right) \cdot V}{m}$

where $q_{e}$ is the amount of metal ions adsorbed on the clay ( $\mu \mathrm{mol} / \mathrm{g}), C_{0}$ and $C_{e}$ are the initial concentrations in solution $(\mu \mathrm{M})$, respectively, $V$ is the volume of the medium $(\mathrm{L})$, and $m$ the mass of the clay sample $(\mathrm{g})$.

The influence of initial metals concentration on the sorption of $\mathrm{Cu}$ (II) and $\mathrm{Zn}$ (II) onto original and treated clay was studied by varying the concentrations tested from $150 \mu \mathrm{M}$ to $1.6 \mathrm{mM}$ and 100 to $600 \mu \mathrm{M}$ for single and binary systems, respectively, as were the temperature $\left(25^{\circ} \mathrm{C}\right)$, clay concentration $(1 \mathrm{~g} / \mathrm{L})$, and metal solution $\mathrm{pH}$ (6). To study the effect of $\mathrm{pH}$, the initial $\mathrm{pH}$ of the solution was adjusted to $2,3,4,5$, or 6 . The contact time in the $\mathrm{pH}$ experiments was fixed at $60 \mathrm{~min}$, and the shaking rate was $200 \mathrm{rpm}$; metal concentrations were held at $600 \mu \mathrm{M} \mathrm{Cu}$ (II) and $300 \mu \mathrm{M} \mathrm{Zn}$ (II). Temperature effect was evaluated by conducting this method at 25,30 , and $35^{\circ} \mathrm{C}$, while maintaining the initial $\mathrm{pH}$ at 6 , contact time at $60 \mathrm{~min}$, and clay concentration at $1 \mathrm{~g} / \mathrm{L}$.

\section{Adsorption isotherm models}

Langmuir and Freundlich isotherm models were used in this study to establish the relationship between the amount of adsorbed metal onto clays and its equilibrium concentration in aqueous system.

Langmuir adsorption isotherm (Langmuir 1918) is based on the assumption of monolayer adsorption onto a surface with a finite number of identical sites. Langmuir isotherm could be arranged in its linear form as following:

$\frac{C_{e}}{q_{e}}=\frac{C_{e}}{q_{m}}+\frac{1}{K_{L} q_{m}}$

where $C_{e}$ is equilibrium concentration of the metal $(\mu \mathrm{M})$ and $q_{\mathrm{e}}$ is the amount of the metal adsorbed per gram of adsorbent $(\mu \mathrm{mol} / \mathrm{g}) . q_{m}$ and $K_{L}$ are Langmuir constant relating adsorption capacity $(\mu \mathrm{mol} / \mathrm{g})$ and the energy of adsorption $(\mathrm{L} / \mathrm{g})$, respectively. These constants can be calculated from the slope and intercept of the linear plots of $C_{e} / q_{e}$ versus $C_{e}$, respectively.

The dimensionless parameter of adsorption $\left(R_{L}\right)$ (defined as $R_{L}=\frac{1}{1+K_{L} C_{0}}$, where $C_{0}(\mu \mathrm{M})$ is the initial concentration) was used as an indicator to assess the extent of adsorption.

Depending on the $R_{L}$ value, there are four possibilities for adsorption: (1) favorable adsorption if $0<R_{L}<1$, (2) unfavorable adsorption when $R_{L}>1$, (3) linear adsorption for $R_{L}=1$, and (4) irreversible adsorption for $R_{L}=0$ (Sari et al. 2007; Baccar et al. 2010).

The adsorption data were also fitted to Freundlich isotherm (Freundlich 1906), which is described by the linear form following the equation:

$\log q_{e}=\log K_{F}+n \log C_{e}$

where $K_{F}$ and $n$ are Freundlich constants, determined from the intercept and slope of the linear plot of $\log q_{e}$ versus $\log C_{e}$.

\section{Thermodynamic parameters}

The removal of copper and zinc by natural clay samples was studied from thermodynamic viewpoint to ascertain the nature of adsorption process under the condition of the current study. To achieve this goal, three thermodynamic parameters, including Gibbs free energy $\left(\Delta G^{\circ}\right)$, enthalpy $\left(\Delta H^{\circ}\right)$, and entropy change $\left(\Delta S^{\circ}\right)$, were determined by the following equations (Eloussaief and Benzina 2010; Eloussaief et al. 2011; Ozdes et al. 2011)

$K_{d}=\frac{C_{s}}{C_{e}}$

$\Delta G^{\circ}=-R T \ln K_{d}$

$\ln K_{d}=\frac{\Delta S^{\circ}}{R}-\frac{\Delta H^{\circ}}{R T}$

where $C_{s}$ and $C_{e}$ are the removed and remaining concentrations, respectively. $K_{d}$ is the distribution coefficient for the adsorption, $\Delta S^{\circ}, \Delta H^{\circ}$, and $\Delta G^{\circ}$ are the changes of entropy, enthalpy, and the Gibbs energy, $T(\mathrm{~K})$ is the temperature, and $R(8.314 \mathrm{~J} / \mathrm{mol} \mathrm{K})$ is the gas constant. The values of $\Delta H^{\circ}$ and $\Delta S^{\circ}$ were determined from the slopes and intercepts of the plots of $\ln K_{d}$ versus $1 / T$.

Model validation

To evaluate the fit of the above-mentioned theoretical models to the experimental data, linear coefficients of determination and non-linear $\chi^{2}$ test were used. The linear coefficient of determination, $R^{2}$, represents the percentage 
of variability in the dependent variable that has been explained by the regression line.

The $\chi^{2}$ test statistic was also used to calculate the sum of the squares of the differences between the experimental data and those calculated from the model. The equivalent mathematical statement could be described as following:

$\chi^{2}=\sum \frac{\left(q_{e}-q_{e, m}\right)^{2}}{q_{e, m}}$

where $q_{e}$ and $q_{e, m}$ are the experimental and calculated the equilibrium capacity $(\mathrm{mg} / \mathrm{g})$, respectively. If the data obtained from the model are similar to the experimental data, $\chi^{2}$ will be a small number, if not, and $\chi^{2}$ will be a bigger number.

\section{Results and discussion}

Characterization of clay samples

Chemical analysis by XRF showed that the original (RS and RY) and treated (TS) clays are mainly composed of silica, aluminum, and iron oxides (Table 1). The results indicated that RS clay, collected from Gafsa area, contained high amount of calcium, and its chemical composition was significantly affected by acetic acid treatment. In comparison between RS and TS, the percentage of silica increased from 40.096 to $57.144 \%$, with a significant

Table 1 Physicochemical properties of the studied clay samples

\begin{tabular}{llll}
\hline Chemical composition (\% by weight) & $\mathrm{RS}$ & $\mathrm{RY}$ & $\mathrm{TS}$ \\
\hline $\mathrm{SiO}_{2}$ & 40.096 & 57.567 & 57.144 \\
$\mathrm{Al}_{2} \mathrm{O}_{3}$ & 16.320 & 21.138 & 22.495 \\
$\mathrm{Fe}_{2} \mathrm{O}_{3}$ & 7.386 & 10.181 & 9.891 \\
$\mathrm{CaO}$ & 26.667 & 2.370 & 2.372 \\
$\mathrm{MgO}$ & 4.667 & 3.615 & 2.751 \\
$\mathrm{TiO}_{2}$ & 1.158 & 1.111 & 1.472 \\
$\mathrm{~K}_{2} \mathrm{O}$ & 3.060 & 1.744 & 3.604 \\
$\mathrm{Na}_{2} \mathrm{O}$ & $\mathrm{nd}$ & 0.605 & - \\
$\mathrm{P}_{2} \mathrm{O}_{5}$ & 0.429 & 0.901 & 0.015 \\
$\mathrm{CuO}$ & 0.002 & 0.003 & $\mathrm{nd}$ \\
$\mathrm{ZnO}$ & 0.018 & 0.020 & 0.024 \\
$\mathrm{Structural}$ parameters & & & \\
$S_{\mathrm{BET}}$ (m $\left.{ }^{2} / \mathrm{g}\right)$ & 17.843 & 71.940 & 10.222 \\
Fine fraction of $<2 \mu \mathrm{m}(\%)$ & 42.751 & 88.533 & - \\
Moisture content $(\%)$ & 16.365 & 15.794 & - \\
$\mathrm{CEC}$ [cmol$(+) / \mathrm{kg}$ ] & 37.450 & 36.871 & 20.171 \\
Total pore volume $\left(\mathrm{cm}{ }^{3} / \mathrm{g}\right)$ & 0.042 & 0.123 & - \\
\hline
\end{tabular}

nd Not detected increase in the mass fraction of aluminum and iron oxides. The data also indicated that the fraction of $\mathrm{CaO}$ and $\mathrm{MgO}$ decreased from 26.667 to $2.372 \%$ and from 4.667 to $2.751 \%$, respectively. Based on the chemical properties, it was expected that the studied clay samples show variable adsorptive behaviors.

The specific surface areas of the original and treated clay samples $(<210 \mu \mathrm{m}$-sized powders) were estimated to be $17.843,71.841$, and $10.222 \mathrm{~m}^{2} / \mathrm{g}$ for $\mathrm{RS}, \mathrm{RY}$, and TS, respectively (Table 1 ). The obtained FTIR spectra of the bulk (RS and RY) and the decarbonated (TS) clay samples showed the stretching vibrations of the surface hydroxyl groups ( $\mathrm{Si}-\mathrm{Si}-\mathrm{OH}$, or $\mathrm{Al}-\mathrm{Al}-\mathrm{OH}$ ) near at 3,694.94 and $3,619.73 \mathrm{~cm}^{-1}$. The other vibration at $1,635.34 \mathrm{~cm}^{-1}$ was attributed to the bending of adsorbed water (Sdiri et al. 2011, 2012b). The stretching bands near 1,435.34, 871.67, and $711.60 \mathrm{~cm}^{-1}$, found in the original sample, were assigned to calcite, but disappeared after the removal of carbonate minerals by acid treatment (Sdiri et al. 2010, 2011). Detailed mineralogical, geological, and spectroscopic characterization of the studied clay samples can be found in Sdiri et al. (2011, 2012b).

\section{Adsorption in single-element system}

The adsorption of the selected metal ions was carried out with concentrations of $\mathrm{Zn}$ (II) $300 \mu \mathrm{M}$ and $\mathrm{Cu}$ (II) $600 \mu \mathrm{M}$ under the operating $\mathrm{pH}$ of 6 and agitation speed of $200 \mathrm{rpm}$ within the equilibrium time of $60 \mathrm{~min}$. As shown in Fig. 1, more than $315 \mu \mathrm{mol} / \mathrm{g}$ of $\mathrm{Cu}(\mathrm{II})$ was removed by RS due to the precipitation as metal carbonate, but the removal capacity decreased to $165 \mu \mathrm{mol} / \mathrm{g}$ for TS because of the removal of carbonate minerals. Due to the presence of carbonates minerals, $\mathrm{Cu}(\mathrm{II})$ removal occurred mainly via the precipitation of copper carbonates $\left(\mathrm{CuCO}_{3}\right)$. The lower precipitation $\mathrm{pH}$ of $\mathrm{CuCO}_{3}(\mathrm{pH} 6)$ and the solubility product constant $\left(K_{\mathrm{sp}}=1.4 \times 10^{-10}\right.$ at $\left.25^{\circ} \mathrm{C}\right)$ would explain this phenomenon. Above $\mathrm{pH} \mathrm{6}$, solid phase of $\mathrm{CuCO}_{3}$ should form, leading to a high sorption capacity, since the equilibrium $\mathrm{pH}$ increased to 7.7 after the addition of carbonaceous clay (RS sample). The same behavior was observed with $\mathrm{Zn}$ (II) removal, but to a much lower extent. This was expected because of the higher precipitation $\mathrm{pH}(\mathrm{pH}$ 6.8) for zinc carbonates; therefore, lower solubility constant $\left(K_{\mathrm{sp}}=1.4 \times 10^{-11}\right.$ at $25^{\circ} \mathrm{C}$ ) (Al-Degs et al. 2006). Sdiri et al. (2012b) mentioned that carbonaceous materials have high affinity to $\mathrm{Cu}$ (II) and $\mathrm{Pb}$ (II) due to their enhanced relative binding strength. As for RY clay, the removal efficiency was lower than the original RS clay because of the small amounts of carbonate (Table 1). 

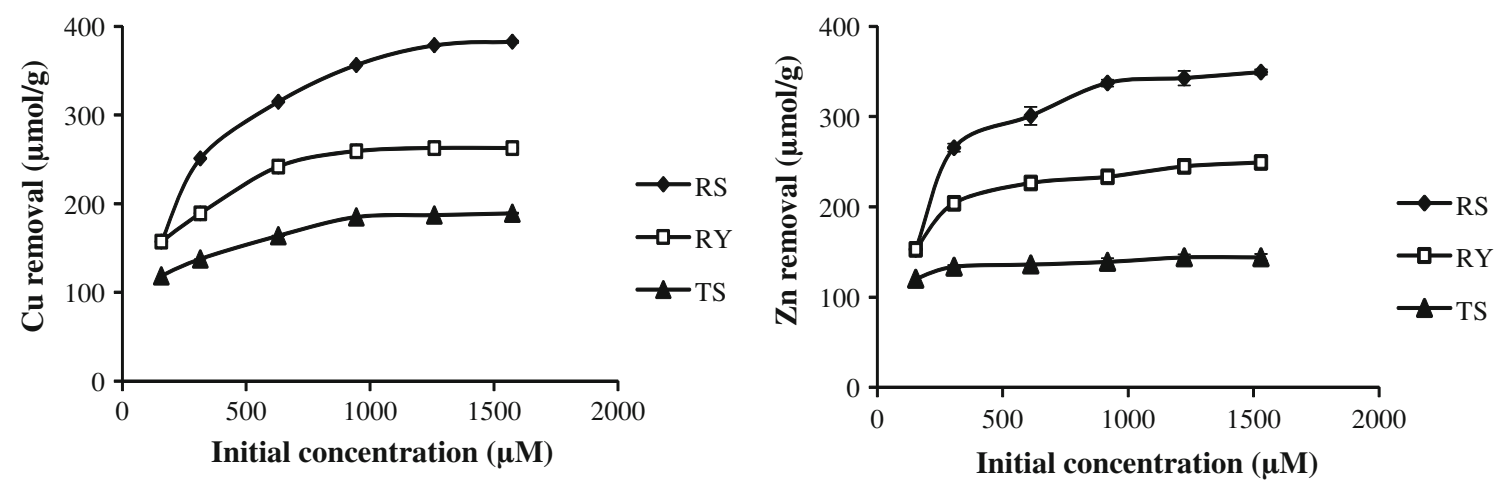

Fig. 1 Effect of initial concentration on $\mathrm{Cu}(\mathrm{II})$ and $\mathrm{Zn}$ (II) adsorption onto natural clays

\section{Effect of initial concentration}

The effect of initial concentration on the adsorption of $\mathrm{Cu}$ (II) and $\mathrm{Zn}$ (II) was carried out with concentrations of $150,300,600,900,1,300$, and $1,600 \mu \mathrm{M}$ under the operating $\mathrm{pH}$ of 6 and agitation speed of $200 \mathrm{rpm}$ within the equilibrium time of $60 \mathrm{~min}$. As shown in Fig. 1, the removal amount increased with increasing initial metal concentration until the saturation of available adsorption site. After that, metal cations will not be adsorbed anymore and the adsorbed amount will attain a plateau. Our results indicated that 600 and $300 \mu \mathrm{M}$ were the optimal concentrations for $\mathrm{Cu}(\mathrm{II})$ and $\mathrm{Zn}(\mathrm{II})$ removal, respectively; they were used in all subsequent experiments. Carbonaceous clay (RS sample) showed the highest removal efficiency due to precipitation as metal carbonate. After the equilibration time of $60 \mathrm{~min}$, the removal of $\mathrm{Zn}$ (II) decreased from more than 265.550 to $133.685 \mu \mathrm{mol} / \mathrm{g}$ because of the removal of carbonate minerals. The same behavior was observed with $\mathrm{Cu}(\mathrm{II})$ as described earlier. In comparison with RY clay sample, the original RS clay removed higher amounts of copper and zinc, but the treated form showed much lower removal efficiency (Fig. 1). Thus, it was clear that the removal of both metals was strongly influenced by carbonate content.

\section{Adsorption isotherms}

The isotherm constants for the removal of $\mathrm{Cu}$ (II) and $\mathrm{Zn}$ (II) are summarized in Table 2. Our results showed that the calculated Freundlich parameters $\left(k_{F}\right.$ and $\left.n\right)$ indicate favorable adsorption $(0<n<1)$. In addition, the separation factor $\left(R_{L}\right)$ varied between 0 and 1 , confirming favorable adsorption under the experimental conditions of the study (Table 2). The maximum adsorbed capacity $q_{0}$, calculated from Langmuir model, reached $434.78 \mu \mathrm{mol} / \mathrm{g}$. Moreover, the high coefficient of correlation $\left(R^{2} \approx 1\right)$ indicated that Langmuir isotherm fitted the experimental data better than Freundlich isotherm. Sdiri et al. (2011) applied the D-R model to clarify the adsorption nature of various metal cations onto montmorillonitic and calcareous clay. The adsorption energy $(E)$ was less $8 \mathrm{~kJ} / \mathrm{mol}$, suggesting a physical removal process.

\section{Effect of contact time}

The effect of equilibration time on the sorption of copper and zinc was analyzed kinetically over a range of 5-120 min. The reaction was stimulated by shaking with clay samples (raw and carbonate-free samples) at $200 \mathrm{rpm}$ at $25{ }^{\circ} \mathrm{C}$ for $60 \mathrm{~min}$ to reach equilibrium with the initial metal solution of pH6. The initial solution concentration was $600 \mu \mathrm{M}$ and $300 \mu \mathrm{M}$ for $\mathrm{Cu}$ (II) and $\mathrm{Zn}(\mathrm{II})$, respectively, while the amount of clay was $1 \mathrm{~g} / \mathrm{L}$. Figure 2 indicate that more than $95 \%$ of the total adsorptive capacity occurred within $30 \mathrm{~min}$, after what the removal further increased but with a much slower rate. From theoretical point of view, adsorption process requires long equilibration time, while the practical approach needs a short contact time. Based on the kinetic results, an equilibration time of $60 \mathrm{~min}$ was selected as a compromise between theoretical and practical approach.

Both metals [i.e., $\mathrm{Cu}(\mathrm{II})$ and $\mathrm{Zn}(\mathrm{II})$ ] were removed faster by the RY sample than any of the others, confirming the significant role of chemisorption as a removal mechanism for zinc, as well as for copper. In the carbonaceous clay (RS), metal binding was lower at the beginning of the experiment, probably because of the surface interaction (physisorption) combined with slow dissolution of carbonate minerals that usually constitutes the first step of metal removal by carbonates (Sanchez and Ayuso 2002; Aziz et al. 2008; Sdiri et al. 2012a). However, the difference in removal rates between the RS and RY samples gradually diminished with contact time, and the effects of carbonates was clearly shone after 
Table 2 Adsorption isotherm constant values for Freundlich and Langmuir models in single and binary systems

\begin{tabular}{|c|c|c|c|c|c|c|c|c|c|}
\hline & \multicolumn{4}{|c|}{ Freundlich } & \multicolumn{5}{|l|}{ Langmuir } \\
\hline & $k_{F}$ & $n$ & $R^{2}$ & $\chi^{2}$ & $q_{0}(\mu \mathrm{mol} / \mathrm{g})$ & $k_{L}(\mathrm{~L} / \mu \mathrm{mol})$ & $R_{L}$ & $R^{2}$ & $\chi^{2}$ \\
\hline \multicolumn{10}{|c|}{ Single system } \\
\hline \multicolumn{10}{|c|}{ Copper } \\
\hline RS & 146.882 & 0.142 & 0.9139 & 130.502 & 434.783 & 0.188 & 0.949 & 0.9891 & 84.421 \\
\hline RY & 90.823 & 0.162 & 0.8903 & 2.791 & 277.778 & 0.472 & 0.979 & 0.9946 & 4.757 \\
\hline TS & 51.619 & 0.19 & 0.9737 & 0.469 & 204.082 & 0.259 & 0.963 & 0.9893 & 3.364 \\
\hline \multicolumn{10}{|l|}{ Zinc } \\
\hline $\mathrm{RS}$ & 199.620 & 0.080 & 0.9350 & 1982.918 & 344.828 & 0.069 & 0.125 & 0.9979 & 6.346 \\
\hline RY & 12.886 & 0.456 & 0.7965 & 4.456 & 238.095 & 0.097 & 0.093 & 0.9936 & 7.990 \\
\hline TS & 134.325 & 0.005 & 0.1251 & 2.885 & 161.290 & 0.008 & 0.552 & 0.9915 & 1.342 \\
\hline \multicolumn{10}{|c|}{ Binary system } \\
\hline \multicolumn{10}{|c|}{ Copper } \\
\hline RS & 24.559 & 0.514 & 0.8721 & 212.029 & 370.370 & 0.029 & 0.255 & 0.9325 & 29.763 \\
\hline RY & 23.551 & 0.339 & 0.9774 & 24.319 & 172.414 & 0.030 & 0.245 & 0.9952 & 5.055 \\
\hline TS & 25.991 & 0.282 & 0.8954 & 15.732 & 140.845 & 0.034 & 0.229 & 0.9814 & 3.583 \\
\hline \multicolumn{10}{|l|}{ Zinc } \\
\hline RS & 28.018 & 0.084 & 0.9552 & 1.750 & 38.168 & 0.198 & 0.048 & 0.9976 & 0.998 \\
\hline RY & 37.829 & 0.178 & 0.8575 & 265.205 & 102.041 & 0.114 & 0.080 & 0.9986 & 2.363 \\
\hline TS & 25.476 & 0.112 & 0.9557 & 240.094 & 49.751 & 0.098 & 0.092 & 0.9987 & 0.323 \\
\hline
\end{tabular}
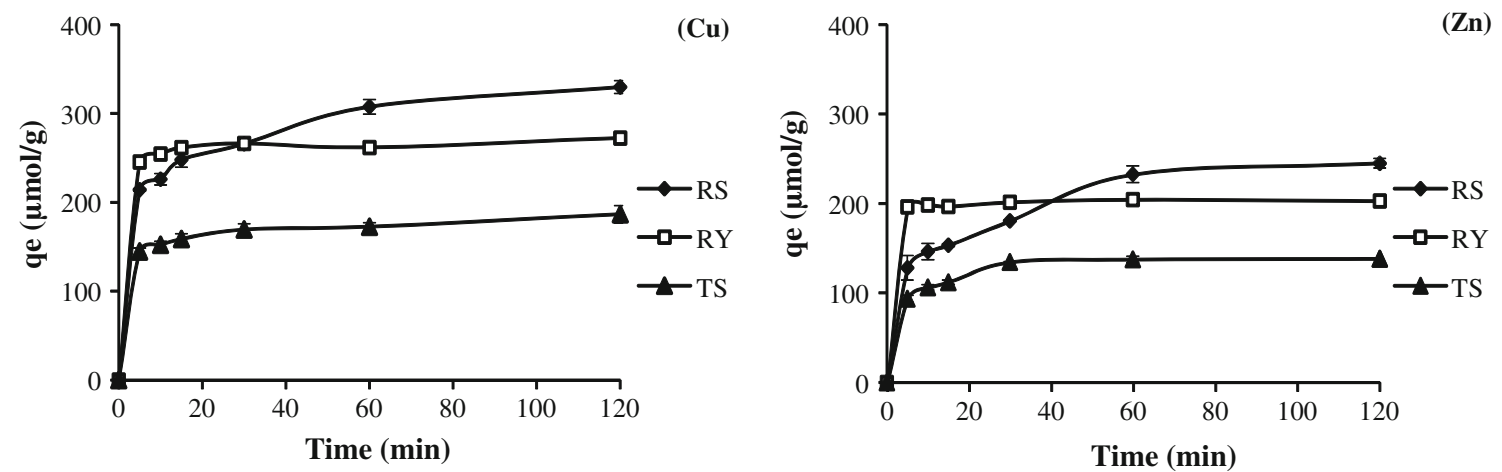

Fig. 2 Effect of contact time on $\mathrm{Cu}(\mathrm{II})$ and $\mathrm{Zn}(\mathrm{II})$ adsorption onto natural clays

$60 \mathrm{~min}$ (Fig. 2), suggesting an enhanced removal efficiency by RS clay.

\section{Effect of $p H$}

The initial solution $\mathrm{pH}$ was varied from 2 to 6 while maintaining the other parameters constant. Effects of initial solution $\mathrm{pH}$ on the removal of $\mathrm{Cu}(\mathrm{II})$ and $\mathrm{Zn}(\mathrm{II})$ are shown in Fig. 3, indicating that the sorption capacity of both copper and zinc onto natural clays increased with $\mathrm{pH}$ (Fig. 3) due to the increase of surface negative charge. This was expected because of the fact that in acidic environment $(\mathrm{pH}<4)$, the sorption of metal ions was suppressed by the excessive presence of $\mathrm{H}^{+}$which compete for available reactive sites. $\mathrm{pH}$ increase was combined with augmentation of removal rates and gradual decrease of $\mathrm{H}^{+}$competitive effects. It is noteworthy to mention that the sorption capacity of the calcareous clay (RS) was stable in the $\mathrm{pH}$ range of 4-6, indicating a possible ion-exchange mechanism. This finding could be ascribed to the contribution of precipitation as metal carbonates.

Our results confirmed that the initial solution $\mathrm{pH}$ is a key adsorption parameter that strongly affects heavy metal 

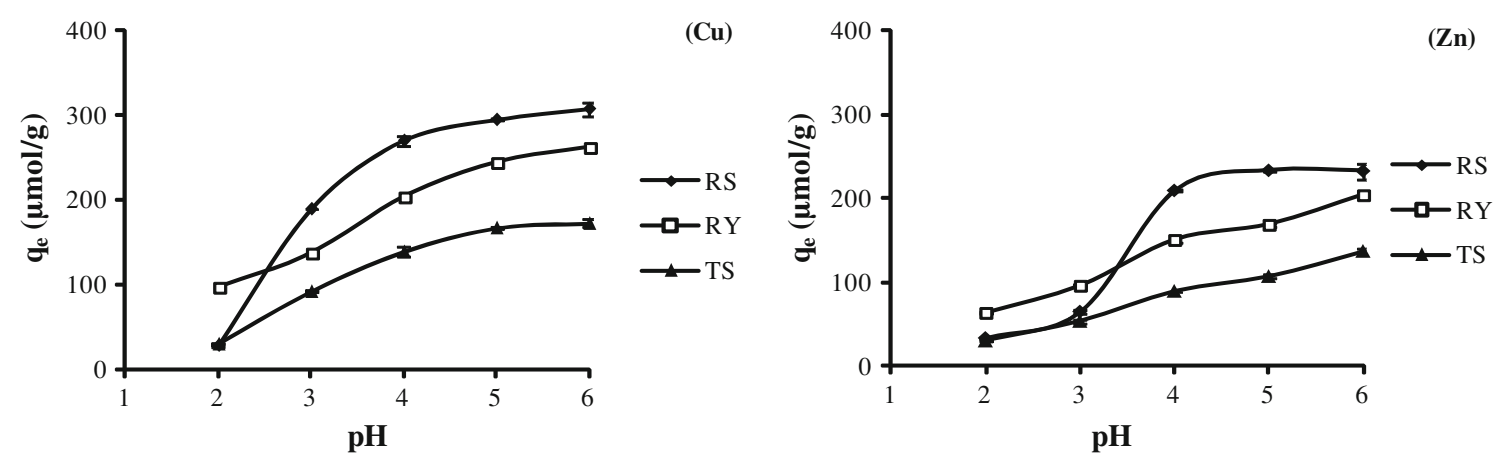

Fig. 3 Effect of initial $\mathrm{pH}$ on $\mathrm{Cu}(\mathrm{II})$ and $\mathrm{Zn}$ (II) adsorption onto natural clays

removal because of the decrease of positive charges on the adsorbent surface with increasing the solution $\mathrm{pH}$ (Eloussaief et al. 2009).

The possible removal mechanisms that may take place near neutral $\mathrm{pH}$ involve precipitations as metal hydroxides according to the following reactions:

$$
\begin{aligned}
& \mathrm{Cu}(\mathrm{II})+2 \mathrm{OH} \Leftrightarrow \mathrm{Cu}(\mathrm{OH})_{2} \\
& \mathrm{Zn}(\mathrm{II})+2 \mathrm{OH} \Leftrightarrow \mathrm{Zn}(\mathrm{OH})_{2}
\end{aligned}
$$

The theoretical precipitation $\mathrm{pH}$ calculated from solubility products was 7.75 and 8.66 for $\mathrm{Cu}(\mathrm{OH})_{2}$ $\left(K_{\mathrm{sp}}=2.2 \times 10^{-20} \quad\right.$ at $\left.25^{\circ} \mathrm{C}\right) \quad$ and $\mathrm{Zn}(\mathrm{OH})_{2}$ $\left(K_{\mathrm{sp}}=1.2 \times 10^{-17}\right.$ at $\left.25^{\circ} \mathrm{C}\right)$, respectively. However, the experimental precipitation $\mathrm{pH}$ was 5.78 and 7.30 for $\mathrm{Cu}(\mathrm{OH})_{2}$ and $\mathrm{Zn}(\mathrm{OH})_{2}$ as ascertained from the maximum concentration of copper and zinc, respectively. These values were calculated from the following equation (AlDegs et al. 2006):

$\mathrm{pH}_{\mathrm{ppt}}=14-\log \sqrt{\frac{\mathrm{M}^{2+}}{K_{\mathrm{sp}}}}$

where $\mathrm{pH}_{\mathrm{ppt}}$ is precipitation $\mathrm{pH}$ and $\mathrm{M}^{2+}$ is metal concentration $(\mathrm{mol} / \mathrm{L})$.

The removal of copper and zinc by carbonaceous clay occurred via precipitation of metal carbonates with a substantial contribution to the total sorption capacities in aqueous solution. It was found that more than $40 \%$ of the total removal capacities were achieved by carbonates impurities found in the natural clay sample. For instance, acetic acid treatment decreased the removal capacity of copper with $44 \%$. Sanchez and Ayuso (2002), Karageorgiou et al. (2007), Sdiri et al. (2012a), and Sdiri and Higashi (2013) mentioned that calcite dissolution preceded the interaction of metal cations with reactive sites at the surface of the sorbent. The mutual interactive behavior of carbonates and metal ions could be described by the following reactions (Al-Degs et al. 2006):
Table 3 Thermodynamic parameters of $\mathrm{Cu}(\mathrm{II})$ and $\mathrm{Zn}$ (II) adsorption onto natural clays

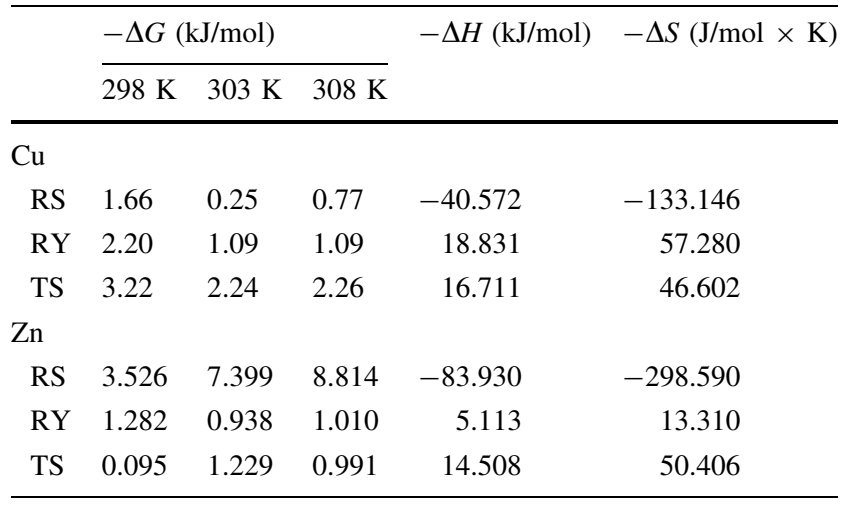

$\mathrm{CaCO}_{3(\mathrm{~s})} \leftrightarrow \mathrm{Ca}_{(\mathrm{aq})}^{2+}+\mathrm{CO}_{3(\mathrm{aq})}^{2-}$

$\mathrm{CO}_{3(\mathrm{aq})}^{2-}+\mathrm{M}_{(\mathrm{aq})}^{2+} \leftrightarrow \mathrm{MCO}_{3(s)}$

In addition, the ion exchange may also operate as a possible sorption mechanism as follows:

$$
\begin{gathered}
\mathrm{M}^{2+}+\mathrm{CaCO}_{3} \Leftrightarrow x \cdot \mathrm{Ca}^{2+}+\mathrm{M}_{y} \mathrm{Ca}_{(1-x)} \mathrm{CO}_{3} \\
+(1-y) \cdot \mathrm{M}^{2+}
\end{gathered}
$$

\section{Effect of temperature}

The effect of temperature on the sorption of $\mathrm{Cu}$ (II) and $\mathrm{Zn}$ (II) onto natural clay samples was studied at 25,30 , and $35^{\circ} \mathrm{C}$. The thermodynamic parameters are listed in Table 3. The sorption capacity of both metals by the original RS clay increased as temperature increased from 298 to $308 \mathrm{~K}$ indicating an endothermic sorption process (Fig. 4). The positive $\Delta H^{\circ}$ value further indicated the endothermic process. The decrease of sorbed amounts with temperature suggests an exothermic sorption process, as indicated by negative $\Delta H^{0}$ values.

The changes in entropy $\left(\Delta S^{\circ}\right)$ were $-133.146,57.260$, and $46.602 \mathrm{~J} / \mathrm{mol} \times \mathrm{K}$ for copper removal by RS, RY, and 

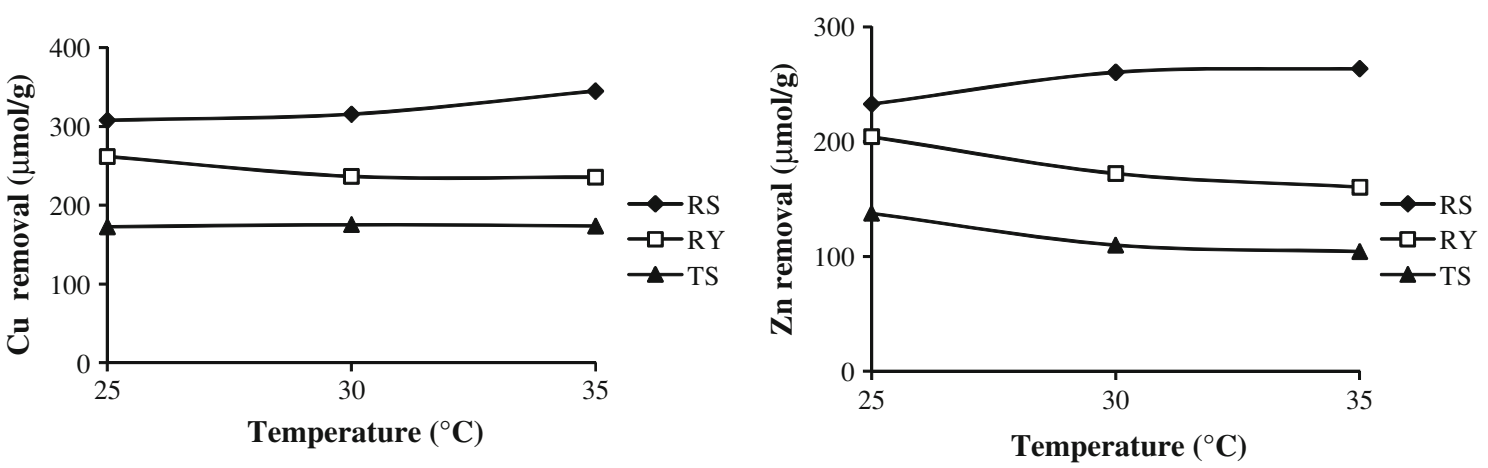

Fig. 4 Effect of temperature on $\mathrm{Cu}(\mathrm{II})$ and $\mathrm{Zn}$ (II) adsorption onto natural clays

TS, respectively. The negative value of $\Delta S^{\circ}$ indicated that the reactions occurred via an arrangement of metal cations at the surface of the sorbent. This is an additional proof for the precipitation of metal carbonates, while the positive value of RY and TS indicated an enhanced disorder during the sorption reaction (Unuabonah et al. 2007). The change of free energy $\left(\Delta G^{0}\right)$ for all metals was negative indicating that the sorption of both metals onto natural clays (i.e., original and treated) was spontaneous in nature (Table 3 ).

\section{Adsorption in binary system}

Figure 5 shows the removal quantities of $\mathrm{Cu}$ (II) and $\mathrm{Zn}$ (II) by the original and treated clay samples at $\mathrm{pH} 6$ in binary systems. The results showed that $\mathrm{Cu}$ (II) showed the highest removal efficiency with the removal amounts in the presence of $\mathrm{Zn}$ (II) of 199.210, 126.780 and $108.226 \mu \mathrm{mol} / \mathrm{g}$ for RS, RY and TS samples, respectively. The carbonaceous clay (RS) removed $199.210 \mu \mathrm{mol} / \mathrm{g}$ of $\mathrm{Cu}(\mathrm{II})$, but dramatically decreased for its carbonate-free form (TS) (Fig. 5). Thus, the presence of carbonates in RS sample enhanced $\mathrm{Cu}$ (II) removal because of the precipitation of $\mathrm{CuCO}_{3}$. In contrast, smectitic clay samples (RY) showed an intermediate removal capacities that is lower
Table 4 Inhibitory effect of a metal on the adsorption of competing metals

\begin{tabular}{lccc}
\hline Sample & Inhibited & \multicolumn{2}{c}{ Inhibitor } \\
\cline { 3 - 4 } & & $\mathrm{Cu}(\mathrm{II})$ & $\mathrm{Zn}(\mathrm{II})$ \\
\hline $\mathrm{RS}$ & $\mathrm{Cu}(\mathrm{II})$ & - & 10.179 \\
& $\mathrm{Zn}(\mathrm{II})$ & 88.501 & - \\
$\mathrm{RY}$ & $\mathrm{Cu}(\mathrm{II})$ & - & 46.422 \\
& $\mathrm{Zn}(\mathrm{II})$ & 62.603 & - \\
$\mathrm{TS}$ & $\mathrm{Cu}(\mathrm{II})$ & - & 18.704 \\
& $\mathrm{Zn}(\mathrm{II})$ & 72.222 & - \\
\hline
\end{tabular}

than the original sample (RS), but somewhat higher than its treated from (TS). The removal efficiency of $\mathrm{Zn}$ (II) decreased substantially in the presence of $\mathrm{Cu}$ (II) compared with single-element system (Figs. 1, 5). Therefore, $\mathrm{Cu}$ (II) strongly depressed $\mathrm{Zn}$ (II) adsorption with an inhibitory effect on $\mathrm{Zn}(\mathrm{II})$ removal [defined as IE $(\%)=\frac{\mathrm{Zn}_{(\mathrm{Zn})}-\mathrm{Zn}_{(\mathrm{Cu}-\mathrm{Zn})}}{\mathrm{Zn}_{(\mathrm{Zn})}}$ where $\mathrm{Zn}_{(\mathrm{Zn})}$ and $\mathrm{Zn}_{(\mathrm{Cu}-\mathrm{Zn})}$ are $\mathrm{Zn}(\mathrm{II})$ removal quantity $(\mu \mathrm{mol} / \mathrm{g})$ in single and binary system, respectively] of $88.5,62.6$, and $72.22 \%$ for RS, RY, and TS samples, respectively (Table 4). Inversely, the inhibitory effect of $\mathrm{Zn}$ (II) on $\mathrm{Cu}$ (II) removal occurred to a much
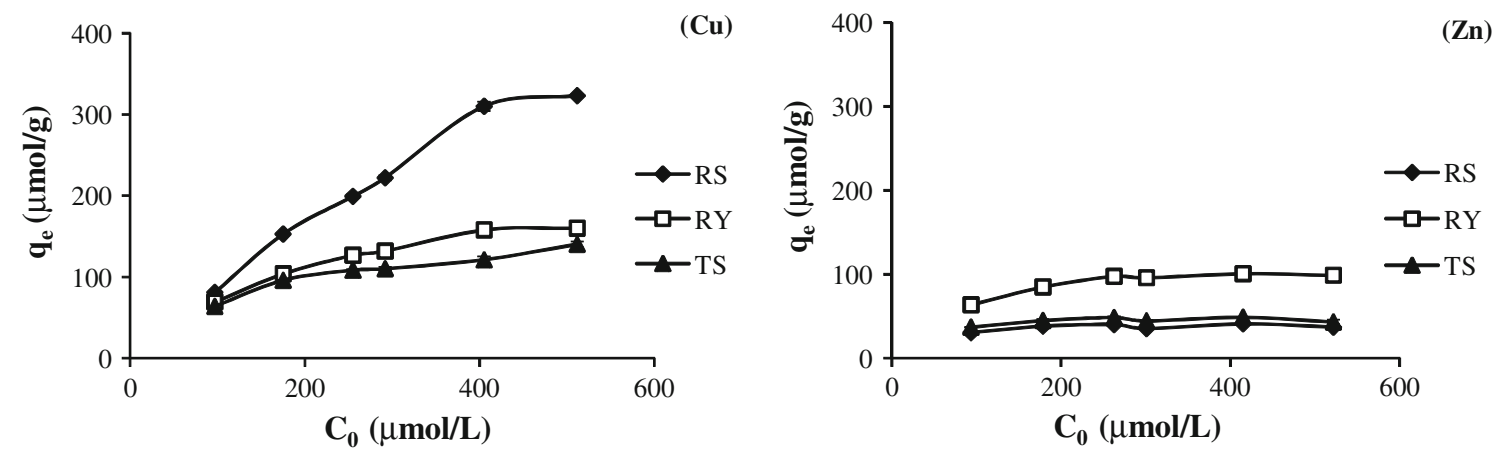

Fig. 5 Adsorption of $\mathrm{Cu}(\mathrm{II})$ and $\mathrm{Zn}(\mathrm{II})$ by natural clays in binary systems 
Table 5 Comparison of Langmuir constant in single and binary systems

\begin{tabular}{|c|c|c|c|c|}
\hline \multirow[t]{2}{*}{ Sample } & \multirow[t]{2}{*}{$\frac{\left(q_{0, \mathrm{Cu}}\right)_{(S)}}{\left(q_{0, \mathrm{Zn}}\right)_{(S)}}$} & \multicolumn{2}{|c|}{$P_{i}=\frac{\left(q_{0, i}\right)_{(S)}}{\left(q_{0, i}\right)_{(M)}}$} & \multirow[t]{2}{*}{$\frac{\left(q_{0, \mathrm{Cu}}\right)_{(M)}}{\left(q_{0, \mathrm{Zn}}\right)_{(M)}}$} \\
\hline & & $\mathrm{Cu}(\mathrm{II})$ & $\mathrm{Zn}(\mathrm{II})$ & \\
\hline $\mathrm{RS}$ & 1.261 & 1.174 & 9.034 & 9.704 \\
\hline RY & 1.167 & 1.611 & 2.333 & 1.690 \\
\hline TS & 1.265 & 1.449 & 3.242 & 2.831 \\
\hline
\end{tabular}

lower extent because of the higher selectivity for $\mathrm{Cu}(\mathrm{II})$ combined with the low competitive ability of $\mathrm{Zn}$ (II) with regards to $\mathrm{Cu}(\mathrm{II})$, despite their similar ionic radii. The calculated inhibitory effects of $\mathrm{Zn}$ (II) on $\mathrm{Cu}$ (II) were $10.18,46.42$, and $18.70 \%$ for RS, RY, and TS, respectively. This was expected since $\mathrm{Cu}$ (II) was predominantly adsorbed by all the studied samples over $\mathrm{Zn}$ (II) because of its higher relative binding strength and lower ionization potential (Sdiri et al. 2012b).

The competitive Langmuir (CLM) and $P$ factor models were applied to the experimental result to analyze competitive sorption behaviors of copper and zinc. The CLM is an extended form of the Langmuir model that allows predicting the amount of a sorbed solute $i$ per unit weight of a sorbent, $q_{i}$ in the presence of other solutes. The CLM isotherm can be described by the following equation (Srivastava et al. 2006; Park et al. 2012):

$q_{i}=\frac{k_{L, i} q_{0, i} C_{i}}{1+\sum_{j=1}^{2} k_{L, j} C_{j}}$

where $q_{i}(\mu \mathrm{mol} / \mathrm{g})$ and $C_{i}(\mu \mathrm{mol} / \mathrm{L})$ are the solid phase and the liquid phase equilibrium concentration of a solute $i$ in bi-solute competitive sorption, respectively. $q_{0, i}(\mu \mathrm{mol} / \mathrm{g})$ and $k_{L, i}(\mathrm{~L} / \mu \mathrm{mol})$ are the parameters determined by fitting the Langmuir model to the single-solute sorption data of solute $i$.

$P$ factor model was also used to simulate the competitive sorption behavior of copper and zinc in bi-solute system. This model assumed a simplified approach to compare and correlate single-solute sorption with those of the multi-component systems by introducing a "lumped" capacity factor $P_{i}$ (Valderama et al. 2010):

$P_{i}=\frac{\left(q_{0, i}\right)_{(S)}}{\left(q_{0, i}\right)_{(M)}}$

where $\left(q_{0, i}\right)_{(S)}$ and $\left(q_{0, i}\right)_{(M)}$ are the sorbent monolayer capacity for component $i$ in single and binary component systems, respectively.

Table 6 Comparison of adsorption capacity with those of previous removal studies with natural clays

\begin{tabular}{|c|c|c|c|c|}
\hline \multirow[t]{2}{*}{ Adsorbent } & \multicolumn{2}{|c|}{ Adsorption capacity $(\mu \mathrm{mol} / \mathrm{g})$} & \multirow[t]{2}{*}{$\mathrm{pH}$} & \multirow[t]{2}{*}{ References } \\
\hline & $\mathrm{Cu}$ & $\mathrm{Zn}$ & & \\
\hline \multicolumn{5}{|l|}{ Single system } \\
\hline $\mathrm{RS}$ & 307.651 & 232.722 & 6 & Present study \\
\hline RY & 261.701 & 204.434 & & \\
\hline $\mathrm{TS}$ & 172.473 & 137.615 & & \\
\hline Fly ash & 140.002 & 115.000 & $4-5$ & Pehlivan et al. (2006) \\
\hline Illitic clay & 207.723 & - & 5.5 & Eloussaief et al. (2009) \\
\hline Sewage sludge & 295.107 & 166.667 & 5 & Gupta et al. (2009) \\
\hline Red mud & 310.326 & 192.508 & 7 & Lopez et al. (1998) \\
\hline Hydroxyapatite & 16.000 & 15.000 & - & Corami et al. (2007) \\
\hline Natural bentonite & - & 159.021 & 4 & Kaya and Hakan Ören (2005) \\
\hline Natural bentonite & - & 195.719 & & \\
\hline \multicolumn{5}{|c|}{$\mathrm{Cu}-\mathrm{Zn}$ binary system } \\
\hline $\mathrm{RS}$ & 276.335 & 26.584 & 6 & Present study \\
\hline RY & 202.216 & 76.652 & & \\
\hline TS & 140.214 & 38.226 & & \\
\hline Calcareous soil & 12.589 & 4.587 & 6.7 & Mesquita and Vieira e Silva (1996) \\
\hline Acid soil & 20.002 & 6.004 & & Arias et al. (2006) \\
\hline Hydroxyapatite & 1510.009 & $1,170.030$ & - & Corami et al. (2007) \\
\hline Illite & 157.366 & 64.220 & - & Oubagaranadin et al. (2010) \\
\hline
\end{tabular}


Our results indicated that the removal of copper and zinc better fitted to the Langmuir isotherm in single and binary systems. The maximum sorption capacities calculated from Langmuir model in bi-solute system were lower than those calculated in single-solute system, because of the existence of competing metal ion.

Effects of competitive metals on the sorption of heavy metals (i.e., copper and zinc) onto natural clays are summarized in Table 5. $\frac{\left(q_{0, \mathrm{Cu}}\right)_{(S)}}{\left(q_{0, \mathrm{Zn}}\right)_{(S)}}$ and $\frac{\left(q_{0, \mathrm{Cu}}\right)_{(M)}}{\left(q_{0, \mathrm{Zn}}\right)_{(M)}}$ ratios were higher than unity indicating the predominant sorption of copper over zinc in single and binary system. This further indicates the preferential sorption of copper over zinc due to its physical properties. In all cases, the high $P_{i}$ values $\left(P_{i}>>1\right)$ confirmed that the sorption was hindered by the presence of competing ions. It was worth to mention that the sorption of $\mathrm{Zn}(\mathrm{II})$ showed high $P_{i}$ value when compared with $\mathrm{Cu}$ (II) because of the strong inhibitory effect that exert the latter on $\mathrm{Zn}$ (II) removal, especially for the original clay (RS clay).

\section{Comparison to other studies}

Based on previous relevant studies, the amount of heavy metals removed by various clay materials is highly variable (Table 6). In the current study, calcareous clay sample (RS) demonstrated an enhanced removal rate when compared with the treated form (TS) and smectitic clay (RY). Sdiri et al. $(2011,2012 b)$ mentioned that the removal efficiency was dependent upon the physicochemical characteristics of the clay and the metal removed, which was the case of the present clay samples. After the removal of carbonates, the calculated Langmuir capacity decreased from 434.783 to $204.082 \mu \mathrm{mol} / \mathrm{g}$ for copper removal by the calcareous clay sample, confirming the tight relationship between the physicochemical properties of the adsorbent and its removal capacity. These results indicate much higher removal efficiency for the present clay samples than that shown by Bhattacharyya and Gupta (2008), who reviewed the removal of metals like lead, cadmium, and copper by various kinds of clay (Table 6). We found that the natural clay from southern Tunisia exhibited greater removal efficiency than those reported in the literature, confirming their beneficial use for the removal $\mathrm{Cu}$ (II) and $\mathrm{Zn}$ (II) from aqueous solutions.

\section{Conclusion}

Calcareous clay of the Coniacian-Early Campanian Aleg formation, Tunisia, showed high removal capacities due to the presence of carbonates impurities, suggesting its potential use as metal sorbent. The adsorption of $\mathrm{Cu}(\mathrm{II})$ and $\mathrm{Zn}$ (II) in single and binary systems fitted to the Langmuir isotherm. In binary system, the adsorption capacity decreased for each metal due to competitive effect. Nevertheless, the removal of $\mathrm{Cu}(\mathrm{II})$ ions showed greater potential than the removal of $\mathrm{Zn}(\mathrm{II})$ in the presence of $\mathrm{Cu}(\mathrm{II})$. Our study showed that good adsorptive capacities could be achieved under the operating conditions of 60 min contact time, $\mathrm{pH} 6$, and clay concentration of $1 \mathrm{~g} / \mathrm{L}$ at $25^{\circ} \mathrm{C}$. The obtained results demonstrated the predominant role of carbonate impurities in the removal of $\mathrm{Cu}(\mathrm{II})$ and $\mathrm{Zn}(\mathrm{II})$. Therefore, the precipitation as metal carbonates may be effectively involved as immobilization mechanism. The positive $\Delta H^{\circ}$ value for the sorptive removal of $\mathrm{Cu}(\mathrm{II})$ and $\mathrm{Zn}$ (II) by the carbonaceous clay (RS) indicated an endothermic process. However, sorptions by the smectitic clay (RY) and the acetic acid treated clay (TS) were exothermic $\left(\Delta H^{\circ}<0\right)$. The negative $\Delta G^{\circ}$ values confirmed the feasibility of sorption processes and their spontaneous nature. Despite these trends in thermodynamic values, it seems that the retention of $\mathrm{Cu}(\mathrm{II})$ and $\mathrm{Zn}(\mathrm{II})$ by natural clays was independent from temperature in the range investigated. Therefore, it can be concluded that the effect of carbonate overwhelmed that of temperature in the condition of our study. Finally, the use of natural clay from the Aleg formation, Tunisia, as a starting material to develop claybased cost-effective adsorbents with enhanced surface area and strong adsorptive capacities for various environmental pollutants in aqueous systems, could be envisaged.

Acknowledgments The authors gratefully acknowledge the financial support provided by the Ministry of Higher Education and Scientific Research, Tunisia, in cooperation with the Japan Bank for International Cooperation (JBIC). The help of Professor Tamao Hatta and his assistant Mrs. Seiko Nemoto, JIRCAS, Tsukuba, Mr. Koichi Shimotori, research associate in the Chemical Analysis Division, University of Tsukuba, is greatly appreciated. Thanks are also extended to Dr. Mohamed Shenashen, Dr. Emad El-Sheehy and Mr. Mohamed Khairy from NIMS for their help.

\section{References}

Ahmad A, Ghufran R, Faizal WM (2010) Cd(II), Pb(II) and Zn(II) removal from contaminated water by biosorption using activated sludge biomass. Clean Soil Air Water 38(2):153-158

Al-Degs YS, El-Barghouthi MI, Issa AA, Khraisheh MA, Walker GM (2006) Sorption of $\mathrm{Zn}(\mathrm{II}), \mathrm{Pb}(\mathrm{II})$, and $\mathrm{Co}(\mathrm{II})$ using natural sorbents: equilibrium and kinetic studies. Water Res 40(14): 2645-2658

Arias M, Perez-Novo C, Lopez E, Soto B (2006) Competitive adsorption and desorption of copper and zinc in acid soils. Geoderma 133(3-4):151-159 
Aziz HA, Adlan MN, Ariffin KS (2008) Heavy metals (Cd, Pb, Zn, $\mathrm{Ni}, \mathrm{Cu}$ and $\mathrm{Cr}(\mathrm{III})$ ) removal from water in Malaysia: post treatment by high quality limestone. Bioresour Technol 99(8): $1578-1583$

Baccar R, Blánquez P, Bouzid J, Feki M, Sarrà M (2010) Equilibrium, thermodynamic and kinetic studies on adsorption of commercial dye by activated carbon derived from olive-waste cakes. Chem Eng J 165(2):457-464

Barhoumi S, Messaoudi I, Deli T, Saïd K, Kerkeni A (2009) Cadmium bioaccumulation in three benthic fish species, Salaria basilisca, Zosterisessor ophiocephalus and Solea vulgaris collected from the Gulf of Gabes in Tunisia. J Environ Sci 21(7):980-984

Bhattacharyya KG, Gupta SS (2008) Adsorption of a few heavy metals on natural and modified kaolinite and montmorillonite: a review. Adv Colloid Interface Sci 140:114-131

Corami A, Mignardi S, Ferrini V (2007) Copper and zinc decontamination from single- and binary-metal solutions using hydroxyapatite. J Hazard Mater 146(1-2):164-170

Das N (2012) Remediation of radionuclide pollutants through biosorption-an overview. Clean Soil Air Water 40(1):16-23

Dubey A, Shiwani S (2012) Adsorption of lead using a new green material obtained from Portulaca plant. Int $\mathrm{J}$ Environ Sci Technol 9:15-20

Eloussaief M, Benzina M (2010) Efficiency of natural and acidactivated clays in the removal of $\mathrm{Pb}$ (II) from aqueous solutions. J Hazard Mater 178(1-3):753-757

Eloussaief M, Jarraya I, Benzina M (2009) Adsorption of copper ions on two clays from Tunisia: $\mathrm{pH}$ and temperature effects. Appl Clay Sci 46(4):409-413

Eloussaief M, Kallel N, Yaacoubi A, Benzina M (2011) Mineralogical identification, spectroscopic characterization, and potential environmental use of natural clay materials on chromate removal from aqueous solutions. Chem Eng J 168(3):1024-1031

Engates KE, Shipley HJ (2011) Adsorption of $\mathrm{Pb}, \mathrm{Cd}, \mathrm{Cu}, \mathrm{Zn}$, and $\mathrm{Ni}$ to titanium dioxide nanoparticles: effect of particle size, solid concentration, and exhaustion. Environ Sci Pollut Res $18: 386-395$

Eren E (2010) Adsorption performance and mechanism in binding of azo dye by raw bentonite. Clean Soil Air Water 38(8):758-763

Eren E, Afsin B, Onal Y (2009) Removal of lead ions by acid activated and manganese oxide-coated bentonite. J Hazard Mater 161(1-3):677-685

Freundlich HMF (1906) Over the adsorption in solution. J Phys Chem $57: 385-470$

Guerra DL, Bastita AC, Corrêa da costa PC, Viana RR, Airoldi C (2010) Adsorption of arsenic ions on Brazilian sepiolite: effect of contact time, $\mathrm{pH}$, concentration, and calorimetric investigation. J Colloid Interface Sci 346(1):178-187

Gupta VK, Carrott PJM, Ribeiro Carrott M, Suhas ML (2009) Lowcost adsorbents: growing approach to wastewater treatment-a review. Crit Rev Environ Sci Technol 39:783-842

Jarraya I, Fourmentin S, Benzina M, Bouaziz S (2010) VOCs adsorption on raw and modified clay materials. Chem Geol 275(1-2):1-8

Karageorgiou K, Paschalis M, Anastassakis GN (2007) Removal of phosphate species from solution by adsorption onto calcite used as natural adsorbent. J Hazard Mater 139(3):447-452

Kaya A, Hakan Ören A (2005) Adsorption of zinc from aqueous solutions to bentonite. J Hazard Mater 125(1-3):183-189

Langmuir I (1918) The adsorption of gases on plane surfaces of glass, mica and platinum. J Am Chem Soc 40:1361-1403

Lin SH, Juang RS (2002) Heavy metal removal from water by sorption using surfactant-modified montmorillonite. J Hazard Mater 92(3):315-326
Lopez E, Soto B, Arias M, Nunez A, Rubinos D, Barral T (1998) Adsorbent properties of red mud and its use for wastewater treatment. Water Res 32(4):1314-1322

Mesquita ME, Vieira e Silva JM (1996) Zinc adsorption by a calcareous soil. Copper interaction. Geoderma 69(1-2):137-146

Messaoudi I, Barhoumi S, Saïd K, Kerkeni A (2009) Study on the sensitivity to cadmium of marine fish Salaria basilisca (Pisces: Blennidae). J Environ Sci 21(11):1620-1624

Oubagaranadin JUK, Murthy ZVP, Mallapur ZVP (2010) Removal of $\mathrm{Cu}(\mathrm{II})$ and $\mathrm{Zn}$ (II) from industrial wastewater by acidactivated montmorillonite-illite type of clay. C R Chim 13(11): 1359

Ozdes D, Duran C, Senturk HB (2011) Adsorptive removal of Cd(II) and $\mathrm{Pb}$ (II) ions from aqueous solutions by using Turkish illitic clay. J Environ Manag 92(12):3082-3090

Park Y, Shin WS, Choi SJ (2012) Removal of Co, Sr and Cs from aqueous solution using self-assembled monolayers on mesoporous supports. Korean J Chem Eng 29(11):1556-1566

Pehlivan E, Cetin S, Yanik BH (2006) Equilibrium studies for the sorption of zinc and copper from aqueous solutions using sugar beet pulp and fly ash. J Hazard Mater 135(1-3): 193-199

Revathi M, Saravanan M, Chiya AB, Velan M (2012) Removal of copper, nickel, and zinc ions from electroplating rinse water. Clean Soil Air Water 40(1):66-79

Sanchez AG, Ayuso EA (2002) Sorption of Zn, Cd and Cr on calcite. Application to purification of industrial wastewaters. Miner Eng 15(7):539-547

Sari A, Tuzen M, Citak D, Soylak M (2007) Equilibrium, kinetic and thermodynamic studies of adsorption of $\mathrm{Pb}$ (II) from aqueous solution onto Turkish kaolinite clay. J Hazard Mater 149(2):283-291

Schaller MS, Koretsky CM, Lund TJ, Landry CJ (2009) Surface complexation modeling of $\mathrm{Cd}(\mathrm{II})$ adsorption on mixtures of hydrous ferric oxide, quartz and kaolinite. J Colloid Interface Sci 339(2):302-309

Sdiri A, Higashi T (2013) Simultaneous removal of heavy metals from aqueous solution by natural limestones. Appl Water Sci 3(1):29-39

Sdiri A, Higashi T, Hatta T, Jamoussi F, Tase N (2010) Mineralogical and spectroscopic characterization, and potential environmental use of limestone from the Abiod formation, Tunisia. Environ Earth Sci 61(6):1275-1287

Sdiri A, Higashi T, Hatta T, Jamousssi F, Tase N (2011) Evaluating the adsorptive capacity of montmorillonitic and calcareous clays on the removal of several heavy metals in aqueous systems. Chem Eng J 172(1):37-46

Sdiri A, Higashi T, Jamoussi F, Bouaziz S (2012a) Effects of impurities on the removal of heavy metals by natural limestones in aqueous systems. J Environ Manage 93(1):245-253

Sdiri A, Higashi T, Chaabouni R, Jamoussi F (2012b) Competitive removal of heavy metals from aqueous solutions by montmorillonitic and calcareous clays. Water Air Soil Pollut 223(3):1194-1204

Srivastava VC, Mall ID, Mishra IM (2006) Equilibrium modelling of single and binary adsorption of cadmium and nickel onto bagasse fly ash. Chem Eng J 117(1):79-91

Ulmanu M, Marañón E, Fernández Y, Castrillón L, Anger I, Dumitriu D (2003) Removal of copper and cadmium ions from diluted aqueous solutions by low cost and waste material adsorbents. Water Air Soil Pollut 142:357-373

Unuabonah EI, Adebowale KO, Olu-Owolabi BI (2007) Kinetic and thermodynamic studies of the adsorption of lead (II) ions onto phosphate-modified kaolinite clay. J Hazard Mater 144(1-2): 386-395 
Valderama C, Barios JI, Ferran A, Cortina JL (2010) Evaluating binary sorption of phenol/aniline from aqueous solutions onto granular activated carbon and hypercrosslinked polymeric resin (MN200). Water Air Soil Pollut 210:421-434
Wang XS, Li ZZ (2009) Competitive adsorption of nickel and copper ions from aqueous solution using nonliving biomass of the marine brown alga Laminaria japonica. Clean Soil Air Water 37(8):663-668 